Por suspeita de infeção bacteriana das lesões com sobreinfeção fúngica iniciou-se Amoxicilina Ácido Clavulânico, Fluconazol e analgesia. Pediu-se hemograma e serologias virais e recomendou-se evicção de alimentos picantes. Após uma semana havia melhoria da tumefação da face e da dor mas mantinha lesões erosivas nas mucosas jugais, fundo do vestíbulo e pavimento oral. Análises sem alterações. Optou-se por biopsar lesões. Antes do resultado anatomopatológico, teve nova agudização com dor acentuada e agravamento das lesões erosivas, nesta altura sem pseudomembranas. Excluído quadro infecioso, iniciou-se corticoterapia tópica com betametasona e sistémica com prednisolona. O resultado anatomopatológico e imunohistoquímico revelou tratar-se de Pênfigo Vulgar. Pediu-se TC de corpo que excluiu síndrome paraneoplásica e encaminhou-se a consulta de Doenças Autoimunes para ajustar corticoterapia e iniciar imunossupressores. Após terapêutica numa primeira fase com deflazacorte $90 \mathrm{mg} /$ dia, azatioprina $50 \mathrm{mg} /$ dia e ciclosporina $300 \mathrm{mg} /$ dia, obteve-se estabilização das queixas intraorais com deflazacorte $30 \mathrm{mg} /$ dia e azatioprina $100 \mathrm{mg} /$ dia. Discussão e conclusões: Sendo uma doença potencialmente fatal (mortalidade de 5 a 15\% se não tratada), o correto diagnóstico e a instituição de uma terapêutica eficaz são fundamentais na redução da morbilidade e no prognóstico. O conhecimento da sua apresentação e uma biópsia das lesões com recurso a exames imunohistoquímicos são fundamentais para o diagnóstico. Por ter um tratamento difícil de ajustar e com riscos importantes devido à imunossupressão e efeitos adversos, estes doentes devem ser seguidos num contexto hospitalar em centros com experiência em doenças autoimunes.

http://doi.org/10.24873/j.rpemd.2019.12.519

\section{\#057 Epidermólise Bolhosa Distrófica: Caso Clínico em Estomatologia Pediátrica}

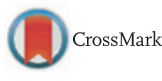

Maria João Morais*, Ana Melissa Marques, Olga Vascan, Beatriz Dominguez, Maria das Dores Lopes, José Pedro Figueiredo

Serviço de Estomatologia - Centro Hospitalar e Universitário de Coimbra, FUMC

Introdução: A Epidermólise Bolhosa Hereditária é uma doença rara, que se manifesta pelo aparecimento de bolhas e lesões espontâneas na pele e na mucosa, em resposta a traumatismos mínimos. Ocorre por mutações genéticas, acometendo as proteínas responsáveis pela coesão entre as diferentes camadas da pele. A Epidermólise Bolhosa divide-se em quatro tipos principais (Simples, Juncional, Distrófica e Síndrome de Kindler), que se distinguem pelas características histológicas, hereditariedade de transmissão - autossómica dominante ou recessiva -, distribuição anatómica das lesões e o nível de clivagem dermo-epidérmica. O diagnóstico é feito através da história clínica, com recurso a biópsia da pele sem bolhas, submetida posteriormente a imunofluorescência direta e/ou microscopia eletrónica. Atualmente, não há um tratamento curativo para a Epidermólise Bolhosa, revelando-se essencial uma abordagem multidisciplinar para proporcionar uma melhor qualidade de vida ao doente. Descrição do caso clínico: Criança do sexo masculino, 8 meses de idade, encaminhada para a consulta de Estomatologia por lesões na cavidade oral em contexto de diagnóstico de Epidermólise Bolhosa do tipo Distrófica autossómica recessiva. A consulta teve como objetivo a avaliação das lesões, orientação do tratamento e prevenção das mesmas, com o propósito de evitar complicações. Foram dados conselhos de higiene oral, dietéticos e reforço da ingestão de água ao longo do dia. Foi prescrita a aplicação de sucralfato na mucosa oral até 3 vezes ao dia, para promoção da cicatrização e da reepitelização da mucosa ulcerada. Discussão e conclusões: A Epidermólise Bolhosa é uma doença complexa com prognóstico grave nos subtipos mais severos. A forma recessiva da Epidermólise Bolhosa distrófica é considerada a mais grave, apresentando lesões orais mais significativas, como microstomia, anquiloglossia, obliteração vestibular e carcinoma de células escamosas. O tratamento incide nos cuidados de suporte, na prevenção e tratamento das lesões a fim de evitar complicações. As medidas de higiene oral, nomeadamente a escovagem diária, o aconselhamento dietético, a administração de flúor e gel de clorohexidina, são fundamentais para evitar o aparecimento de cáries e doença periodontal. http://doi.org/10.24873/j.rpemd.2019.12.520

\section{\#058 Influência do incorreto desenho protético em prótese fixa sobre implantes}

Diogo Soares*, João Manuel Santos Marques, José Mário Rocha, Pedro Fernandes, Francisco Gois, JC Sampaio-Fernandes

\section{FMDUP}

Introdução: O edêntulismo é uma condição irreversível e debilitante descrita como a etapa final de um processo gradual de doença oral. Nesta condição, os pacientes procuram uma solução que não só permita restabelecer eficiência mastigatória e a função fonética, mas também realce a estética facial. A reabilitação fixa sobre implantes é normalmente a solução mais desejada por este tipo de pacientes, devido á comodidade e eficiência mastigatória que lhe está associada, repondo as condições perdidas. Por outro lado, a utilização de próteses removíveis suportadas por implantes, pode em certas situações, permitir melhor estética e maior facilidade na sua higienização. O caso clínico abaixo apresentado, descreve uma reabilitação fixa superior e inferior, que por várias razões, parece não ter sido a melhor opção para esta paciente. Descrição do caso clínico: Paciente totalmente edêntula no maxilar superior e inferior, portadora de prótese fixa superior e inferior realizada por outro profissional há cerca de 10 anos, tendo-se apresentado na consulta do Curso de Especialização em Reabilitação Oral da Faculdade de Medicina Dentária da Universidade do Porto devido ao mau hálito e à dificuldade em higienizar as suas próteses. Verificou-se durante o exame clínico a presença de abas vestibulares em ambas as próteses fixas que comprometiam a correta higienização da mesma. Associado a esta dificuldade, a paciente apresenta dis- 